\title{
Al Wasațiyyah in the Eye of Prophetic Tradition
}

Ahamad Asmadi Sakat ${ }^{2}$
Abur Hamdi Usman'

\section{Doi:10.5901/mjss.2015.v6n2s1p448}

\section{Abstract}

The concept of al wasatiyyah is often referred as the appropriate method to be adopted in the application of all aspects of human life. This is due to the simplicity and balance is the best approach in rejecting extremism in all matters. However the concept which upholds the Islamic principles is still misunderstood by some people. Even some parties put al wasatiyyah as a platform to justify any means to achieve their personal ambitions. Accordingly, in order to provide a thorough understanding of this concept, the study explored its meanings according to Prophet's tradition perspective. Nevertheless, to get the results were more efficient, it will be limited to two main topics, namely al wasatiyyah in faith and worship. In this vein, method of literature and document analysis was applied by discussing both matters in more detail. Thus, to achieve the study objectives, all the prophetic traditions which relevant in this study will assessed in advance in terms of its authenticity before detailing its meaning. The study found that the meaning al wasatiyyah according to prophetic tradition mean just, best, selective, simple and balanced. And from the point of faith this concept can assure the Muslims to be released from the extreme fanatical ideology (ifrāt) and too deficient (tafrït) and to ensure the authentic faith. While in terms of worship, al wasatiyyah can ensure a human deeds to following the Islamic requirement as practiced by the Prophet.

Keywords: Al Wasatiyyah, Faith, Worship, Prophetic tradition.

\section{Introduction}

The emergence of al wasatiyyah concept started when the Prophet (pbuh) revealed to life of humans that lost and worthless, denying the existence of the creator, worshiping of idols, justify the unlawful, etc. The Prophet (pbuh) was sent with the amendment, spreading the message of Islam with straight concept of balance and fairness by inviting people to believe in God and worship Him.

Islam rejects the concept of monkhood in Christianity which forbids themselves to enjoy all the worldly facilities which were allowed, and at the same time also refuses the life style of the Jews who are obsessed with this present life. Thus Islam came to unite the spiritual and physical demands, even behaving in a balanced and fair to both without exaggerative or too deficient in it. Hence, the Prophet said as reported by Ibn 'Abbās:

On the morning of 'Aqabah the Messenger of Allah (pbuh), said while upon his camel: "Pick up some pebbles for me." So I picked up seven pebbles about the size of a pea. He began to toss them in his hand, saying: "Throw something like these." Then he said: "O people, beware of exaggeration in religion for those who came before you were only destroyed because of exaggeration in religion." 1

\footnotetext{
${ }^{1}$ See Ibn Mājah. (2008). Sunan Ibn Mājah, chapter Qadr Hașr al-ramy, vol. 2, p. 1008, Hadith number 3029.
} 
This an authentic hadith is also supported by Sura al-Nisa' (The Women) verse 171 which forbids to exceed the limits in all religious matters. Allah said:

"O People of the Scripture, do not commit excess in your religion or say about Allah except the truth...".

Therefore, the fairness and balance are the spirit that underlies of all aspects the Islamic teachings either on faith or worship. An explanation of the concept of al wasatiyyah in faith, for example has been expressed by al-Qaradāwī (2001) by stating six things, among others: First, al wasatiyyah between extremists who believe in everything without being based on the guidance with those Materialist who denies everything behind the senses and ignores human nature as, reason and miracles excellence. Second, al wasatiyyah between atheists who do not believe in any god and favor of his wits ability only with those who believe in multiple gods with worshiping the animal, idolatry or even stone. Third, al wasatiyyah between those who regard the universe as the only form of rights with those who deny it. Fourth, al wasatiyyah between those who make man as a god and has the power to govern with those who consider people have no power, ground helpless like cotton, and surrender to fate. Fifth, al wasatiyyah between those who are purify the prophets up to the level of divinity, even making it as a child of God by those who reject, punish and reject them. Sixth, al wasatiyyah between those who believe in the ability to reason as the only source to determine the essence of things with those who deny it, but favor the revelation and inspiration.

The above description should be taken seriously by Muslims today, especially for those who practice a secular culture and mentality. As worrying are the implication of the fragility of faith, according to cAbdul Rashīd (2010) could lead the people to a wide range of extreme attitude and taking anything lightly. Though Allah does not tolerate anything even the slightest weakness in faith.

The concept of al wasatiyyah in worship matters was exemplified by the Prophet in his daily lives. He forbids the companions to worships Allah excessively that caused inconvenience to them. He straightened his companions who has an opinion when to forbid themselves from any convenience of life as suspect it could get them closer to God. Hence, the Prophet considers such actions cause someone does not get the recognition as his parishioners. Due to he (as a servant closest to Allah) does not renounce the world, as in his following saying:

It is narrated on the authority of Anas (may Allah be pleased with him) that some of the companions of the Prophet (prayers and peace of Allah be upon him) asked his (the Prophet's) wives about the acts that he performed in private. Someone among them (among his companions) said: I will not marry women; someone among them said: I will not eat meat; and someone among them said: I will not lie down in bed. He (the Holy Prophet) praised Allah and glorified Him, and said: "What has happened to these people that they say so and so, whereas I observe prayer and sleep too; I observe fast and suspend observing it; I marry women also! And he who turns away from my Sunnah, he has no relation with me."2

Recognizing the importance of faith and worship as the pillars of belief, Islam and Muslim life, this study attempts to explain the meaning of al wasatiyyah according to Hadith (prophetic tradition) perspective. Yet evidence from the Qur'an also stated to strengthen the argument. Accordingly, some of both issues has also been mentioned for seeing a clearer view regarding this concept in its efforts to purify and sanctify the Muslims faith and ensuring their practices following the Islamic requirement as practiced by the Prophet.

Hence, it can be acknowledged that al wasatiyyah is an approach much acclaimed by Islam. A comprehensive and integrated approach is capable of solving the demands and problems of the ummah. Actually, al wasatiyyah calls on followers of Islam to practice Islam in a balanced and comprehensive manner in all aspects of life and society by focusing on improving the quality of human life associated with developing knowledge, human development, economic and financial system, political system, nationhood, unity, equality among races etc. (Hanapi, 2014).

\section{The Meaning of Al Wasatiyyah}

The term of al wasatiyyah is rarely defined. Even the simplest definitions have to grapple with a basic definitional problem: moderate in comparison to what? This question can be answered in a variety of ways, each of which involves some kind of normative claim. The simplest approach is a scorecard that defines a moderate based on an explicit set of liberal social and political norms as enshrined in modern international covenants (White, 2012).

${ }^{2}$ See Muslim, Abū al-Husayn. (2005). al-Jāmic al-Șahịị. Chapter istiḥbāb al-nikāḥ liman tāqat nafsahu ilayh, vol. 4, p. 129, hadith number 3469 . 
Hence, the term of al wasatiyyah comes from the root word of wasat which means just (al-Jawharī 1987, 3: 1167), virtousness (Mușțafā, et.al., 2008), middle, balanced or moderate (Fāris, 1979). Actually, the wasaț (middle) is a synonym for virtue, because it is defined as the mid between two bad characters or two bad extremes. For instance, generosity is the wasaț or virtue between niggardliness and extravagance (Ibn Manz̧ūr, 2010) and (al-Asfahānī, 1970).

al-Shamrī (2005) adds that the use of al wasatiyyah term found only in two situations. First, when it is in between the two positions are equally bad, like generosity among stinginess with wasteful. Thus Islam does not accept both of these nature, as the Qur'an denounces the excessive in Sura al-Acraf (The Heights) verse 31 below:

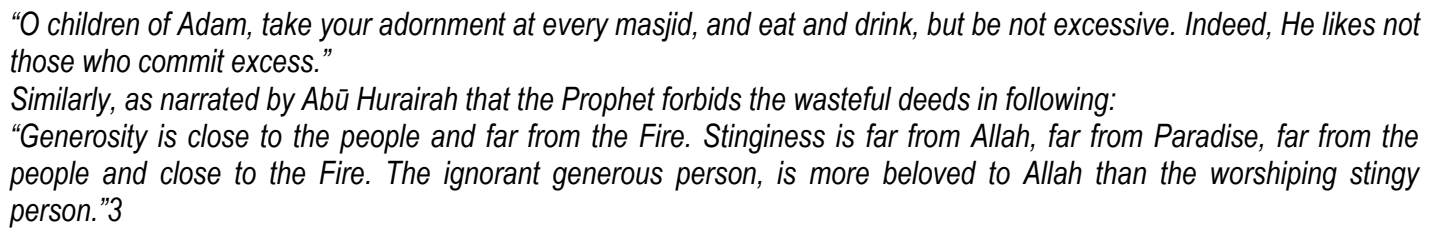

Second, when it is between two conflicting positions (good and bad). Here, the meaning of wasatiyyah is as a metaphor (kināyah) against bad things rather than good. For example, when it is said: "He was in the middle between frugal with stingy", it is meant that he is stingy.

However, the meaning of al wasatiyyah on first condition is the most favorable to follow according to scholars, due to the second condition contains metaphorical meanings, whereas the really meaning is primary to be than followed the metaphor. In addition, if there are two things or opposing sides, then al wasatiyyah become a third party rather than be at one of both. For example, if it is said "Islam is the middle", then it is wrong if Islam meant to be among the truth and the wrong religions, because it understandable that there is a better religion than Islam. Though Islam is the most perfect and the only acceptable religion in the sight of Allah, as mentioned in Sura al-Maidah (The Spread Table) verse 3 and Ali IImran (Family of 'Imran) verse 19.

Based on the above, it can be concluded that wasatiyyah according to the linguistic etymology refers to moderation, fairness, sticking to virtue and balance. As for the meaning of al wasatiyyah in Hadith perspective (terminology) could be described as follows:

i. The justify, as word of the Prophet in following:

\begin{abstract}
Allah's Messenger (pbuh) said, "Noah will be called on the Day of Resurrection and he will say, "Labbaik and Sa'daik, 0 my Lord!" Allah will say, "Did you convey the Message?' Noah will say, "Yes." His nation will then be asked, "Did he convey the Message to you?"They will say, "No Warner came to us." Then Allah will say (to Noah), "Who will bear witness in your favor?" He will say, "Muhammad and his followers. So they (i.e. Muslims) will testify that he conveyed the Message. And the Apostle (Muhammad) will be a witness over yourselves, and that is what is meant by the Statement of Allah." Thus We have made of you a just and the best nation that you may be witnesses over mankind and the Apostle (Muhammad) will be a witness over yourselves." The wasat means the 'Adl (justify). 4
\end{abstract}

This hadith is as an explanation from the meaning Allah's word in sura al-Baqarah (The Cow) verse 143 below:

"And thus we have made you a just community that you will be witnesses over the people and the Messenger will be a witness over you."

According to Abū Hayyān (1993), Ibn ‘Āṭiyah (1993) and al-Samarqandīi (1993) the word wasaț in this verse means fair. Accordingly, al-Zuhaylī (1991) explains that the meaning of al wasațiyyah is selected, just, best and middle in each matter without exceeding any limit and neglect. In the matter of religion, Muslims do not excessive and neglect their duties. This is also consistent with the meaning of Allah's word in sura 'Ali 'Imran verse 110. Hence, al-Qaraḍāwī (2001) noted that the Islamic teachings that is accordance with the concept of al wasatiyyah are impartial in legislative and balanced, unbiased, not outrageous or too less.

ii. The best, as word of the Prophet in following:

The Prophet (pbuh) said, "Whoever believes in Allah and His Apostle offers prayers perfectly and fasts (the month of)

${ }^{3}$ See al-Bayhaqĩ. (1990). Shacbu al-İmān, chap. fĩ al-jawd wa al-sakhā', vol. 7, p. 428, hadith number 10847.

${ }^{4}$ See al-Bukhāri. (1980). Șaḥịh al-Bukhārī, book al-Tafsiri, chap. Wa kadhālika jacalnākum ummatan wasațan, vol. 3, p. 192, Hadith number 4487. 
Ramadan then it is incumbent upon Allah to admit him into Paradise, whether he emigrates for Allah's cause or stays in the land where he was born." They (the companions of the Prophet) said, "O Allah's Messenger (pbuh)! Should we not inform the people of that?" He said, "There are one-hundred degrees in Paradise which Allah has prepared for those who carry on Jihad in His Cause. The distance between every two degrees is like the distance between the sky and the Earth, so if you ask Allah for anything, ask Him for the Firdaus, for it is the last part of Paradise and the highest part of Paradise, and at its top there is the Throne of Beneficent, and from it gush forth the rivers of Paradise."5

This hadith is in accordance with the Allah's word in sura al-Qalam (The Pen) verse 28 below:

"The most moderate of them said, "Did I not say to you, "Why do you not exalt [ Allah ]?"

Ibn Kathir (1999) quoting Ibn 'Abbās exegesis of the words awsațuhum in this verse with 'the best'. al-Tabari (2000) also stated that the meaning of wasaț is khiyār and afḍal (best). Moreover, not a few exegetes who gather the both words (best and justify) without rejecting one of them. Such as al-Zamkhsharī (1998), (al-Shanqițī, 1995) and alHā'im (1992). Despite the both words are different, but have the same meanings. This was due to the just is certainly good and it was just. There is also an addition that awsațuhum means the most ingenious (al-Tha'labī, 2002), al-Baghāwī (1997) and al-Qurțubī (2003).

Based on the above explanation it could be concluded that al wasatiyyah in the angle of terminology is a best approach containing the features of fairness, goodness, middle and balance that emphasizes simplicity in any aspect of life comprehensively, whether spiritual or physical. While hadith was use it in the different context and meanings, but consists entirely of positive meaning. Thus, the terminology itself refers to a praised state in which man is kept from falling into extremism. This term of al wasatiyyah is as old as history itself and it has many synonyms, like moderation, balance, justice and fairness.

\section{The Al Wasatiyyah Concept on Faith}

Even in their faith and creed, Muslims are privileged to have a wasat (balanced and moderate faith). Muslims stand middle between and balanced between polytheists who believe in many gods or in god composed of parts and those who deny the existence of god altogether. Muslims believe in Allah, the One True God, who is unique, sustaining all that exists, does not father nor is born.

Muslims hold a wasat faith regarding Prophet Jesus, son of Mary. While Jews consider him a liar and Christians worship him as god, Muslims take a middle view saying that he is a Prophet and a graduate of the same school of other Prophets including Moses and Muhammad. Even with their great love of Prophet Muhammad which could been seen in the last cartoon issue, not a single Muslim ever said that Muhammad can be worshipped. Yes, Muslims love him and revere him so much but still, al wasatiyyah is the norm that they follow in all states.

Furthermore, if discuss the mission of the Prophets and Messengers, they invite the people to believe in Allah alone without associate anything with Him. Admittedly, the Sharia (Islamic law) was brought is vary, but their religion is one, namely Islam, such as the word of the Prophet (pbuh) as narrated by Abu Huraira in following:

Allah's Messenger (pbuh) said, "Both in this world and in the Hereafter, I am the nearest of all the people to Jesus, the son of Mary. The prophets are paternal brothers; their mothers are different, but their religion is one." 6

al-cAsqalānī (1959) stated that Islamic foundation is the faith, despite its different branches of the Sharia. Similarly, Ibn Kathir (1999), which explains that the similarity between the apostles is invite to worship Allah alone and not associate with any, despite their law was different. The hadith above in accordance with Allah's word in sura al-Maidah (The Table Spread) verse 48 below:

And We have revealed to you, [O Muhammad], the Book in truth, confirming that which preceded it of the Scripture and as a criterion over it. So judge between them by what Allah has revealed and do not follow their inclinations away from what has come to you of the truth. To each of you We prescribed a law and a method. Had Allah willed, He would have made you one nation [united in religion], but [He intended] to test you in what He has given you.

However, the people after them have changed and replace it with something that does not allowed by Allah. This includes in matters of faith, with regard to His substance, names and attributes. They were divided into several groups,

\footnotetext{
${ }^{5}$ See al-Bukhāri. (1980). Șahịḥ al-Bukhārī, book al-jihad wa al-sayr, chap. Darajāt al-Mujāhidīn Fĩ Sabïlilāh, vol. 2, p. 303, Hadis number 2790.

${ }^{6}$ See al-Bukhāri. (1980). Șahịịn al-Bukhärī, book al-Anbiyā', chap. Wadhkur fĩ al-kitāb Maryam, vol. 2, p. 489, Hadith number 3443.
} 
there are being too light (Jewish) and even outrageous (Christians) in understanding and practice it. The Jews, for example, associating Allah with others by worshiping idols, as Allah says in sura al-Acraf (The Heights) verse 138 below:

"And We took the Children of Israel across the sea; then they came upon a people intent in devotion to [some] idols of theirs. They said, "O Moses, make for us a god just as they have gods." He said, "Indeed, you are a people behaving ignorantly."

In addition, they also equate Allah with His creatures and considered Him with weaknesses (al-Shahrastānī, 1968). Among them who refers to him as a poor, as saying in sura Ali c/mrān (Family of Imran) verse 181 below:

"Allah has certainly heard the statement of those [Jews] who said, "Indeed, Allah is poor, while we are rich." We will record what they said and their killing of the prophets without right and will say, "Taste the punishment of the Burning Fire."

As well as the Jews, the Christians were also equalize the creatures with God as they were making Jesus as Lord. Allah says in sura al-Maidah (The Table Spread) verse 17:

"They have certainly disbelieved who say that Allah is Christ, the son of Mary..."

Even they have associated Him with others and became one of their trinity belief. Allah says in sura al-Maidah (The Table Spread) verse 73:

"They have certainly disbelieved who say, "Allah is the third of three." And there is no god except one God."

al-Shahrastānī (1968) explains the confusion, where they also assume that Allah had come down from heaven and have the body of the holy spirit, become a man that was born by Mary, then killed and crucified.

Thus, some of Jews and Christians inverted beliefs in faith issues, particularly with regard to the substance of Allah. They are not only simple and lightweight and has reached to very extreme level. Accordingly, al-Tabari (2000) states that when Allah calls Muslims to al wasatiyyah, it means they are not extremists such as Christians in the monkhood and talk about Jesus with something that does not true. They are not among those who are taking it easy, like the Jews, who reject Allah, change His book, and kill the prophets who were sent to them. Not surprisingly, when Allah described them as misguided and wrath people. The Prophet (pbuh) said:

"Narrated 'Adiy ibn Hâtim: that the Prophet (pbuh) said: "The Jews are those who Allah is wrath with, and the Christians have strayed."7

Thus, the concept of al wasatiyyah in faith according to the Hadith is purifying and reject all superstitions and go astray from the truth, far from the polytheism, misguided, followers of the passions and members of the heterodoxy. It requires belief in one God, and far from the equation with His creatures. In addition, a person also required to believe in the prophets and messengers who were sent as well as the holy books without changing its contents. Al Wasatiyyah in faith according to 'Izzat al-Khayyātț (2006) means stay away from the faith of unification with God, Marxism, Darwinism, Freudianism and other anti God of beliefs.

Therefore, the Prophet asked his people to oneness of Allah, worship Him, and to purify their hearts from all filthiness of polytheism. The Messenger of Allah educate his people to ascribe Allah with all perfection, glory and purify from any imperfection in such His creatures, nor liken it to anything, either in substance or His nature (Ibn Taymiyyah, 2008). By doing so, the practice of al wasatiyyah concept will always adhere to the Qur'an and the Hadith as a sources of pure faith, but at the same time not neglecting the functions of sense which support the truth of revelation. To that end, alGhazali (1992) criticized those who call towards stagnation, confining and limiting the functions of sense. According to alGhazāil (1992) this phenomenon be a soft bastion for Muslims to interact with the Quran correctly. Islam liberates the sense and never stop it, even turn it on and do not freeze its function. However, it does not exceed the ability of the revelation and it should be guided based on the principles set out by the scholars.

Clearly one of the role of al wasatiyyah concept is to maintain the purity of Islamic faith from the deflected to the misguided ideology. Al Wasatiyyah is a manifestation of justice, constancy, kindness, peace, strength and unity in the principles of faith. It was also the requirements as implied by Allah in sura al-Nisa' (The Women) verse 171 that prohibits

7 See al-Tirmidhī. (2010). Sunan al-Tirmidhī, book Tafsīr al-Qur'an, chap. wa min surah al-Fātihaha, vol. 5, p. 204 , hadith number 2954. 
from extremism of the previous nations in faith.

The concept of moderation served Muslims well in the past, allowing them to realize, among other things, toleration of different religious communities in their midst to a considerable extent, according to pre-modern legal conceptions of faith-based citizenship and social status. In our contemporary period, re-emphasis on what has always been a highly important and traditional value for Muslims has begun to lead to significant amplifications and reformulations of the concept of moderation. Moderation defined primarily as just and temperate behavior in various spheres of life allows its application and endorsement as a universal norm. Invoking universal understandings of what constitutes justice and temperateness-among them, a lack of partisanship in assigning moral value to individual actions regardless of that person's religious affiliation and avoidance of injury to another (a definition, as we observed, that was already current among a number of pre-modern Muslim authorities)-moderation can be deployed as a universal socio ethical organizational principle in pursuit of the common good of humanity (Asfaruddin, 2009).

\section{The Al Wasatiyyah Concept on Worship}

Islam is a religion that respects and considers human instinct and deals with man as a human being not as an angel. Being human means, that man has needs and wishes and abilities. Therefore, while performing acts of worship man is commanded to adhere to moderation.

The hadith provides evidence that God wanted His Prophet to be moderate in his recitation of the Scripture. It also inspires Muslims to apply the method of moderation in reciting verses from the Scripture in their daily prayers. This command of God draws the attention of Muslims to realize the significance and necessity of applying moderation in all aspects of life. Even though one reflects enthusiasm and ardent desire for religious ritual, he is not allowed to be extreme or obsessed but follow the middle path as stipulated in the hadith. If this is the Prophet's command in relation to recitation in prayers, then contemplate the consequences when people are inclined to immoderation in other things that are not related to spiritual matters (Ushama, 2014).

Some other hadiths are also recorded regarding the method of moderation. The following is cited to strengthen the present analysis of moderation and its meaning. "On the authority of Jābir ibn cAbd Allāh, the Prophet said, we were with the Prophet and he drew a line (in the sand), then he drew two lines to its right and two to its left. Then he put his hand on the middle line and said: 'This is the path of Allah.' Then he recited verse 153 of Süra al-Ancām (of the Qur'ān) which reads as 'Verily, this is My Way, leading straight: follow it: follow not (other) paths: they will scatter you about from His (great) path: thus doth He command you that ye may be righteous.' The wasat here is a thing between two things, i.e. middle between the two" (Ushama, 2014).

The concept of al wasatiyyah in Islam stands for the middle and openness, which is a position that does not swept away by materialism nor flown soaring into the spiritual world that is not grounded (Shihab, 2011). This characteristic making someone has the ability to combine the spiritual with the physical traits and deeds. In addition, it is also open to all groups whether religion, culture or civilization. This is very important because how can Islam be considered a religion that emphases on justice and being the best, if it is harder, closed or conceal itself from a pluralistic society even to global developments. In short, Islam as a religion that easy, as the word of the Prophet:

Abu Hurairah (May Allah be pleased with him) reported:

The Prophet (pbuh) said, "The religion (of Islam) is easy, and whoever makes the religion a rigor, it will overpower him. So, follow a middle course (in worship); if you can't do this, do something near to it and give glad tidings and seek help (of Allah) at morn and at dusk and some part of night".8

The hadith is also supported by the word of Allah in Sura al-Qasas (The Story) verse 77 which explains that Muslims are required to obtain what has been bestowed by Allah as a reward and happiness of the Hereafter, but they should not forget the needs of the present life.

Al Wasatiyyah concept as practiced by the Prophet in matters of worship can be understood clearly through his words which forbid his ummah to perform the prayers and fasting throughout the morning and evening, causing hardship and pain extremely. The Prophet said:

Narrated 'Abdullah ibn 'Amr: Allah's Messenger (pbuh) was informed that I have said: "By Allah, I will fast all the days and pray all the nights as long as I live." On that, Allah's Messenger (pbuh) asked me. "Are you the one who says: "I will fast all the days and pray all the nights as long as I live?". I said, "Yes, I have said it." He said, "You cannot do that.

${ }^{8}$ See al-Bukhārī. (1980). Șahịḥ al-Bukhārī, book al-Imān, chap. al-Dīn yusr, vol. 1, p. 29, hadis number 39. 
So fast (sometimes) and do not fast (sometimes). Pray and sleep. Fast for three days a month, for the reward of a good deed is multiplied by ten time, and so the fasting of three days a month equals the fasting of a year." 9

The hadith explains the importance to practice al wasatiyyah which does not consider a things with a very simple or even outrageous. The Prophet forbids for perform the prayers or sleep through the night, but prayers and sleep at some time. Similarly, a person is not required to fast or breaking the whole year. But they have to fast in some time. This proves that Islam does not practice the concept of monkhood, but favor the sense of fairness and middle. Thus, Islam opens opportunities for believers to humble themselves in prayer, as it also provides an opportunity to rest. The wisdom behind it, according to al-Nawawī (1929) is to eliminate all forms of harm.

Accordingly, the concept of al wasatiyyah was practiced by the Prophet refers to the middle of the way approach. Mohd Zarif (2012) said it intends to carry out the responsibilities and obligations in a simple, balanced, fair and impartial in accordance with religious requirements. Islam emphasizes the aspect of balance and moderation comprehensively in any aspect of life. Islam provides a balancing policy between the spiritual and the physical, and according to Haron Din (2007) it was acceptable to the original human nature. Allah did not create instinct, passion, and strength in vain. The instinct should be pressed with the good purpose so Muslim can control it for healthy development. Hence, the attitudes which inclined to spiritual and physical are not healthy and realistic to realize the safety, prosperity and happiness in this world and hereafter.

Thus, the concept of al wasatiyyah in worship according to Hadith are the practice of merely follow human capabilities, not too less or too much. Any form of difficulty should be removed so as not to burden the people to worship. The Prophet said:

\begin{abstract}
Narated by Ibn 'Abbas: While the Prophet (pbuh) was delivering a sermon, he saw a man standing, so he asked about that man. They (the people) said, "It is Abu Israil who has vowed that he will stand and never sit down, and he will never come in the shade, nor speak to anybody, and will fast." The Prophet said, "Order him to speak and let him come in the shade, and make him sit down, but let him complete his fast."10
\end{abstract}

In addition, most excellent worship is practiced continuously even though few in number, as the words of the Prophet follows:

Narrated 'Aisha: The Prophet (pbuh) used to construct a loom with a Hasir at night and order to pray therein, and during the day he used to spread it out and sit on it. The people started coming to the Prophet (pbuh) at night to offer the prayer behind him. When their number increased, the Prophet (pbuh) faced them and said: "O people! Do only those good deeds which you can do, for Allah does not get tired (of giving reward) till you get tired, and the best deeds to Allah are the incessant ones though they were few."11

Al-Man (1988) explains that the hadith teaches about the need for a practice that is carried continuously, and the goal is to get the reward for those who always ask Him. Although the practice is just a little bit, but it is more pleasing to Allah from a lot but discontinuous. Due to it seems to turn away from Him after they approach Him before.

Based on the hadiths above clearly indicate the encouragement to be fair and simple, but it forbids to be extreme until omit its natural tendency as human beings.

\title{
5. Conclusion
}

Al Wasatiyyah or moderation is the middle path. It can be termed as an effort to balance the values and find a way that can be accepted by all in the context of a multiracial society. Through al wasatiyyah, Muslims have learned to think and act wisely without being extreme, too rigid or overly liberal. Muslims are taught not to be a fanatic or to be so obsessed that we close our minds to other views, thoughts and opinions. The importance of moderation, adding that there should be peaceful coexistence and mutual respect among people, irrespective of whether they are of the same race or religion.

Muslims gain recognition from Allah as the best ummah. However, the glory of the status requires sacrifices from them. Among the tasks to be undertaken is to adopt of al wasatiyyah in all things. Al Wasatiyyah as a concept that is demanded by the Prophet, since he himself also practiced in his daily life. In the matter of faith for example, he advocates through the hadith to not follow the previous human acts, like the Jews who are taking it easy, and also the Christians

${ }^{9}$ See Muslim. (2005). al-Jāmic al-Șahịhh, chap. al-Nahy can șawm al-dahr liman taḍarrara bih, vol. 3, p. 162, Hadis number 2786.

10 See al-Bukhārī. (1980). Șahīḥ al-Bukhārī, book al-Imān wa al-nudhūr, chap. Bab al-nadhar fimā lā yamlik, vol. 4, p. 229, hadis number 6704.

${ }^{11}$ See al-Bukhārī. (1980). Șahịḥ al-Bukhārī, book al-Libās, chap. Bab al-Julūs calā al-ḥashịir wa nahwihh, vol. 4, p. 67, hadis number 5861. 
with extreme in matters of faith. Through the concept it could be ensured the Muslims faith can be free from the overly fanatical ideology and too less in every single things. To that end, al wasatiyyah in faith must take seriously to oneness of Allah, away from polytheism and so on. Similarly, in worship aspect. Hadith of the Prophet instilling the values of al wasatiyyah that require his ummah to not overdo in worship, bringing trouble on themselves. If difficult, Islam provides facility behind it. Hence, it is hoped that Muslims can continue to excel as the best ummah, maintaining a pure faith, to increase the momentum of worship, do not despair of His mercy and to compete in kindness as contained in this concept.

\section{References}

Abdul Rashīd, Q. (2010). al-Manhaj al-Islāmī li al-wasatịyyah wa al-citidāl. Cairo: Dār al-Salām.

Abū Hayyān, A. (1993). Tafsīr al-Baḥr al-Muhịț. Vol. 1. Beirut: Dār al-Kutub al-cllmiyyah.

al-Asfahānī, R. (1970). al-Mufradāt li gharīb al-Qur'ān. Egypt: Maktabah al-Anjilū.

Asfaruddin, A. (2009). The Hermeneutics Of Inter-Faith Relations: Retrieving Moderation And Pluralism As Universal Principles In Qur'anic Exegeses. Journal of Religious Ethics, JRE 37, 2, pp.331-354.

al-cAsqalānī, I. H. (1959). Fatḥ al-Bārī sharḥ Șahīḥ al-Bukhārī. Vol. 6. Beirut: Dār al-Macrifah.

al-Baghāwī, M. H. (1997). Macālim al-tanzīl. vol. 8. Beirut: Dār al-Ṭayyibah.

al-Bayhaqī, A. B. (1990). Shacbu al-Īmān. Vol. 7. Beirut: Dār al-Kutub al-cllmiyyah.

al-Bukhārī, M. I. (1980). Șahīḥ al-Bukhārĩ. Vols. 1, 2, 3 \& 4. Riyad: al-Salafiah.

al-Jawharī, I. H. (1987). al-Ṣahậ̣ tāj al-lughah wa șaḥāḥ al-cArabiah. Vol. 3. Beirut: Dār al-cllm al-Malāyīn

Fāris, A. H. (1979). Mucjam maqāyis al-lughah. Vol. 6. Beirut: Dār al-Fikr.

al-Ghazāili, M. (1992). Kayfa natacāmal maca al-Qur'ān. Cairo: Dār al-Wafā'.

al-Hāìm, S. A. (1992). al-Tibyān fĩ tafsīr gharīb al-Qur'ān. Vol. 1. Cairo: Dār al-Șaḥābah.

Hanapi, M. S. (2014). The Wasatiyyah (Moderation) Concept in Islamic Epistemology: A Case Study of its Implementation in Malaysia. International Journal of Humanities and Social Science, Vol. 4, No. 9 (1); July 2014.

Haron Din. (2007). Islam: Keadilan membebaskan manusia. Selangor: PTS.

Ibn ‘Āțiyah, A. M. (1993). al-Muharrar al-wajīz. Vol. 1. Beirut: Dār al-Kutub al-cllmiyyah.

Ibn Kathīr, I. (1999). Tafsīi al-Qur'ān al-cAzịim. Vols. 7 \& 8. Damascus: Dār Tayyibah.

Ibn Mājah. (2008). Sunan Ibn Mājah. Vol. 2. Beirut: Dār al-Fikr.

Ibn Manzūur. (2010). Lisān al-cArab. Cairo: Dār al-Macārif.

Ibn Taimiyyah. (2008). Minhāj al-Sunnah al-Nabawiah. Vol. 5. Cairo: al-Madanī.

Izzat al-Khayyāț, A. (2006). Wasațiyyah al-Islām. Cairo: Dār al-Salām.

Al-Manāwī, Z. (1988). al-Taysīr bi sharh al-Jāmic al-Șaghîr. Vol. 1. Riyad: al-Maktabah al-Imām al-Shāfic̄.

Mohd Zarif, M. M. (2012). Satu milennium Islam di Nusantara: Tinjauan Sosio-Sejarah. In Convention of Wasatiyyah held by Nadi Dialog Malaysia, Islamic Science University of Malaysia and JAKIM on 10 to 11 June 2012.

Muslim, A. H. (2005). al-Jāmic al-Șahịḥ. Vols. 1, 3 \& 4. Beirut: Dār al-Jīl.

Mușțafā, I. et.al. (2008). al-Mucjam al-wasiț. Vo. 2. Beirut: Dār al-Dacwah.

al-Nawawī. (1929). Șahị̣̄ Muslim bi sharḥ al-Nawawī. Vol. 8. Cairo: al-Mașriyyah bi al-Azhar.

al-Qaraḍāwī, Y. (2001). al-Khașāis al-cĀmmah li al-Islām. Cairo: Dār al-Macārif.

al-Qurțubī, A. (2003). al-Jāmic li aḥkām al-Qur'ān. Vol. 18. Riyad: Dār al-cĀlam al-Kutub.

al-Samarqandī, A. L. (1993). Baḥr al-cUlūm. Vol. 1. Beirūt: Dār al-Kutub al-cllmiyyah.

al-Shahrastānī, A. K. (1968). al-Milal wa al-nihal. Vols. 1 \& 2. Beirut: Mu'assasah al-Halabī.

al-Shanqịți, M. A. (1995). Aḍwwā'u al-bayān fi ị̣āḥ al-Qur'ān bi al-Qur'ān. Vol. 1. Beirūt: Dār al-Kutub al-cllmiyyah.

al-Shamrī, T. I. (2005). al-Wasațiyyah fi caqidah al-Islāmiah. Beirut: Dār al-Kutub al-cllmiyyah.

Shihab, M. Q. (2011). Membumikan Al-Qur'an jilid 2: Memfungsikan wahyu dalam kehidupan. Jakarta: Lentera Hati.

al-Ṭabarī, J. (2000). Jāmic al-bayān fĩ ta'wīl al-Qur'ān. Vols. 3 \& 23. Beirüt: Mu'assasah al-Risālah.

al-Thaclabī, A. (2002). al-Kashf wa al-bayān. Vol. 10. Beirut: Dār al-lhyā̄' al-Turāth al-cArabī.

al-Tirmidhī, A. I. (2010). Sunan al-Tirmidhī. Vol. 5. Beirut: Dār al-lhyyā’ al-Turāth al-cArabī.

Ushama, T. (2014). Is Islam a Religion of Moderation or Extremism? A Study of Key Islamic Teachings. Asian Social Science, Vol. 10, No. 8; 2014. dx.doi.org/10.5539/ass.v10n8p184.

White, J. T. (2012). Beyond moderation: Dynamics of political Islam in Pakistan. Contemporary South Asia, Vol. 20, No. 2, June 2012, pp. 179-194. dx.doi.org/10.1080/09584935.2012.670200.

al-Zabīdī, M. H. (1966). Tāj al-cArūs min jawāhir al-qāmūs. Vol.5. Beirut: Dār al-Ṣadr.

al-Zamakhsharī, M. (1998). al-Kashshäf. Vol. 6. Riyad: Maktabah al-cAbīkān.

al-Zuhailī, W. (1991). Tafsîr al-munīr. Vol. 2. Beirut: Dār al-Fikr. 